Original Research Paper

\title{
Analisis LC-MS/MS (Liquid Crhomatogaph Mass Spectrometry) dan Metabolit Sekunder serta Potensi Antibakteri Ekstrak $n$-Heksana Spons Callyspongia aerizusa yang diambil pada kondisi tutupan Terumbu Karang yang berbeda di Perairan Teluk Staring
}

\author{
Wa Ode Intiyani Mangurana ${ }^{1 *}$, Yusnaini ${ }^{1}$, Sahidin $^{2}$ \\ ${ }^{1}$ Program Studi Ilmu Perikanan, Pasca Sarjana Universitas Halu Oleo, Kendari, Indonesia \\ ${ }^{2}$ Program Studi Fasmasi, Universitas Halu Oleo, Kendari, Indonesia
}

\section{Riwayat artikel}

Received : 05 April 2019

Revised : 01 Juli 2019

Accepted : 08 Juli 2019

Published : 14 Agustus 2019

*Corresponding Author:

Wa Ode Intiyani Mangurana Program Studi Ilmu Perikanan, Pasca Sarjana Universitas Halu Oleo, Kendari, Indonesia Email:

wimangurana@gmail.com
Abstrak : Spons merupakan bagian dari biota komponen penyusun ekosistem terumbu karang yang memiliki kandungan bioaktif. Salah satu jenis spons yang memiliki kandungan bioaktif adalah $C$. aerizusa. Tujuan dari penelitian ini adalah untuk melihat perbedaan kandungan bioaktif pada kondisi terumbu karang yang berbeda. Metode yang digunakan dalam survei kondisi terumbu karang dan penentuan stasiun pengamatan menggunakan metode Point Intercept Transect (PIT). Pemeriksaan metabolit sekunder menggunakkan metode Kromatografi lapis tipis menurut Harborne (1987), perbedaan kandungan senyawanya menggunakan analisis LC-MS/MS, pengujian aktivitas antibakteri menggunakkan metode sumuran. Hasil penelitian kondisi tutupan karang menunjukan bahwa kondisi tutupan karang hidup 19-65\% dengan kategori buruk hingga baik. Jumlah senyawa pada stasiun I mencapai 15 dan jumlah senyawa pada stasiun II mencapai 13. Kandungan Metabolit Sekunder untuk $C$. aerizusa dari kedua stasiun sama, yaitu aktif terhadap alkoloid, steroid, flavonoid, terpenoid, dan saponin. Potensi Antibakteri Ekstrak $n$-heksana Spons C. aerizusa untuk stasiun I dan II tidak aktif terhadap E. coli namun Spons C. aerizusa stasiun I dan II aktif terhadap aktivitas $S$. mutans.

Kata Kunci : $n$-heksana, Terumbu karang, metabolit sekunder, antibakteri

Abstract : Sponges are part of the biota that make up the coral reef ecosystem that contains bioactive ingredients. One type of sponge that has a bioactive content is $C$. aerizusa. The purpose of this study was to see differences in bioactive content in different coral reef conditions. The method used in the coral reef condition survey and the determination of observation stations using the Point Intercept Transect (PIT) method. Examination of secondary metabolites using the thin layer chromatography method according to Harborne (1987), differences in the content of compounds using LC-MS / MS analysis, testing the antibacterial activity using the well method. The results of the research on coral cover conditions showed that the conditions of live coral cover were $19-65 \%$ with a bad to good category. The number of compounds at station I reached 15 and the number of compounds in station II reached 13. Secondary Metabolite content for C. aerizusa from both stations was equally active against alkoloid, steroid, flavonoids, terpenoids, and saponins. Antibacterial Potential of n-hexane Extract of $C$. aerizusa Sponge for stations I and II were not active against $E$. coli but sponge $C$. aerizusa station I and II were active against S. mutans activity.

Keywords : $n$-hexane, coral reefs, secondary metabolites, antibacterial 


\section{Pendahuluan}

Indonesia merupakan negara dengan keanekaragaman hayati yang tinggi karena letak geografis yang strategis diapit oleh dua samudra (Samudra Hindia dan Pasifik) dan benua (Asia dan Australia), wilayahnya membentang di sepanjang tiga zona waktu, dan bagian dari segitiga karang dunia (Coral triangle initiative), keragaman tipe habitat, variasi iklim yang musiman sehingga memiliki ekosistem-ekosistem potensial (Dahuri, 2003).

Ekosistem Terumbu karang merupakan salah satu ekosistem potensial yang hidup di dasar perairan Indonesia, sebagian besar hidupnya berkoloni tersusun atas kalsium karbonat (CaCO3) yang dihasilkan oleh hewan karang. Spons merupakan bagian dari biota komponen penyusun ekosistem terumbu karang. Spons memiliki kandungan senyawa aktif. Persentase bioaktif spons lebih besar dibanding dengan senyawa-senyawa yang dihasilkan oleh tumbuhan darat (Rachmaniar, 2007).

Spons atau porifera adalah hewan dari phylum porifera yang merupakan salah satu penyusun pada ekosistem pesisir dan laut terutama pada ekosistem terumbu karang yang mempunyai potensi bioaktif sebagai antibakteri, antikanker, antijamur (Rumampuk, 2017). Penelitian yang dilakukan oleh Intiyani (2015) tentang kajian potensi bioaktif spons Callyspongia aerizusa dengan metode kromatografi lapis tipis (KLT) mendapatkan bahwa pada spons tersebut terdapat kandungan alkoloid, flavonoid, steroid dan terpenoid. Hasil penelitian ini didukung oleh hasil penelitian sebelumnya yang dilakukan oleh Krisyuninda pada tahun (2012) yang menyatakan bahwa dalam ekstrak spons laut Callyspongia sp. terdapat senyawa alkoloid, steroid, flavonoid, terpenoid.

Bioaktif merupakan senyawa kimia aktif yang dihasilkan oleh organisme melalui jalur biosintetik metabolit sekunder (Khatab, 2008). Metabolit diklasifikasikan menjadi dua, yaitu metabolit primer dan metabolit sekunder. Metabolit primer yang digunakan untuk pertumbuhan dan kehidupan mahluk hidup yang digunakan untuk pertumbuhan dan kelangsungan hidup diantaranya lemak, DNA, protein dan karbohidrat sedangkan metabolit sekunder tidak digunakan untuk pertumbuhan, melainkan diproduksi oleh organisme dalam jumlah tertentu pada kondisi yang mencekam contoh metabolit sekunder diantaranya adalah antibiotik, pigmen, toksin, efektor kompetisi ekologi dan simbiosis, feromon, inhibitor enzim, agen immunodulasi, reseptor antagonis dan agonis, agen antitumor dan promotor pertumbuhan hewan dan tumbuhan (Nofiani, 2008). Senyawa metabolit sekunder berfungsi untuk menghadapi serangan predator, media kompetisi, mencegah infeksi bakteri, membantu proses reproduksi, dan mencegah sengatan sinar ultraviolet. Karang lunak menghasilkan beberapa dari golongan senyawa hasil metabolit sekunder, antara lain alkaloid, steroid, flavonoid, fenol, saponin, dan peptide (Hardiningtias 2009).

Potensi pemanfaatan spons sangat luas terutama pemanfaatan kandungan zat aktif di bidang kesehatan, Pemanfaatan yang berpotensi pengembangan ekstrak sebagai antibakteri pathogen, biomaterial pada cat, merupakan bagian dari sekian banyak pemanfaatan spons (Marzuki, 2018).

Spons merupakan organisme sesile yaitu hidup menetap, sehingga tidak dapat menghindari serangan predator dengan berpindah tempat, sedangkan ikan bersifat mobile yang dapat berpindah-pindah apabila terjadi tekanan ekologi di sekitarnya. Oleh karena itu, spons memiliki mekanisme pertahanan tubuh secara kimiawi. Mekanisme pertahanan dilakukan dengan cara menghasilkan senyawa bioaktif.

Sumberdaya spons menyebar di perairan sub tropis sampai pada perairan tropis termasuk perairan Sulawesi Tenggara diantaranya perairan Teluk Staring. Secara ekologi, Teluk Staring memiliki kompleksitas ekosistem dan keunikan sumberdaya yang cukup tinggi. Sehingga Teluk Staring ditetapkan sebagai kawasan konservasi perairan daerah (KKPD) oleh Provinsi Sulawesi Tenggara melalui Dinas Kelautan dan Perikanan. KKPD Teluk Staring dikelola dalam bentuk zonasi yang terdiri dari zona inti, zona pemanfaatan terbatas, zona perikanan berkelanjutan dan zona lainnya.

Secara ekologi, zonasi KKPD Teluk Staring terdapat perbedaan ekologi pada setiap zonanya. Perbedaan tersebut diduga kuat berpengaruh pula terhadap kandungan bioaktif pada setiap jenis spons. Fariska 2010, menyatakan bahwa setiap jenis spons dapat berkembang dengan kondisi ekologi yang beragam sehingga menyebabkan bioaktif yang dihasilkan juga dapat bervariasi sesuai dengan adaptasi lingkungan pertumbuhannya yang berbeda. Janssen (2001), mengemukakan produksi metabolit sekunder pada organisme dimodulasi oleh lingkungan seperti, kedalaman, intesitas cahaya, dan pertahanan kimia.

Berdasarkan penjelasan paragraf diatas, penelitian ini penting untuk mengeksplorasi potensi bioaktif spons dengan melihat perbedaan kandungan bioaktif spons pada kondisi ekologi yang berbeda (tutupan karang yang berbeda).

Tujuan dari penelitian ini adalah untuk mengetahui perbedaan kandungan senyawa bioaktif pada ekstrak $n$-heksana spons laut $C$. aerizusa yang diambil pada kondisi tutupan karang yang berbeda. 


\section{Bahan dan Metode}

\section{Waktu dan lokasi penelitian}

Penelitian ini dilaksanakan selama 6 (enam) bulan (Desember 2017-Mei 2018), yang dilakukan dalam di perairan Teluk Staring Kab. Konawe Selatan, Waktu tersebut meliputi survei awal, studi literatur, pengambilan data di lapangan, analisis data dan laboratorium, serta penyusunan laporan akhir. Selain pengambilan sampel spons juga dilakukan pengukuran beberapa parameter lingkungan yaitu kondisi tutupan terumbu karang. Kemudian dilanjutkan dengan analisis metabolit sekunder, uji aktivitas antibakteri serta antioksidan, di laboratorium Farmasi Fakultas Farmasi, Universitas Halu Oleo Kendari, sebagai tempat pelaksanaan analisis laboratorium. Analisis LC-MS/MS di lakukan di BPPT Serpong, Tanggerang Selatan.

\section{Prosedur Penelitian}

Prosedur penelitian pada penelitian ini meliputi:

\section{Survey kondisi terumbu karang dan Penentuan stasiun pengamatan}

Penelitian ini dilakukan pengamatan dengan menggunakan metode Point Intercept Transect (PIT) untuk mengetahui tutupan dasar terumbu karang dan kondisi terumbu karang. Transek dibentangkan sepanjang $50 \mathrm{~m}$ sejajar garis pantai menggunakan meteran rol. Pengamatan dilakukan dengan cara mencatat bentuk-bentuk pertumbuhan karang (life form) dan komponen abiotik yang melewati transek serta mengukur kisaran penutupan bentuk pertumbuhan pada angka yang terbaca pada meteran rol. Pencatatan dilakukan dengan menggunakan alat bantu tulis bawah air atau sabak dan pensil. Secara teknis, metode Point Intercept Transect (PIT) adalah cara menghitung persen tutupan (\% cover) substrat dasar secara acak, dengan menggunakan tali bertanda di setiap jarak 0,5 meter atau juga dengan meteran rol.(Coremap II LIPI, 2017)

Metode Point Intercept Transect (PIT) untuk mengamati kondisi terumbu karang, meliputi bentuk pertumbuhan (life form) karang sesuai dengan metode yang digunakan oleh COREMAP II LIPI dengan beberapa modifikasi. Transek garis yang digunakan sepanjang 50 meter ini akan dilakukan pada setiap stasiun pengamatan, sebanyak 1 ulangan pada suatu kedalaman (3 s/d 8 meter) sesuai dengan kondisi lapangan. Analisis persentase penutupan karang hidup yang diperoleh dengan pengamatan metode PIT dihitung berdasarkan rumus (Coremap II LIPI, 2017) sebagai berikut :

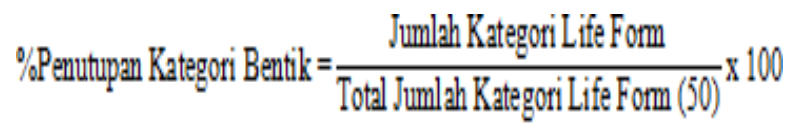

Kondisi penilaian ekosistem terumbu karang berdasarkan persentase penutupan karang hidup mengacu pada Keputusan Menteri Lingkungan Hidup tentang kriteria baku kerusakan Terumbu karang, dapat dilihat pada Tabel 1. Kriteria Baku Kerusakan Terumbu Karang Berdasarkan KEPMEN LH No. 4 Tahun 2001.

Tabel 1. Kriteria Baku Kerusakan Terumbu Karang Berdasarkan KEPMEN LH No. 4 Tahun 2001.

\begin{tabular}{llll}
\hline No. & & Kriteria & Persentase (\%) \\
\hline 1 & & Buruk & $0-24,9$ \\
2 & Rusak & Sedang & $25-49,9$ \\
3 & & Baik & $50-74,9$ \\
4 & Baik & Baik Sekali & $75-100$ \\
\hline
\end{tabular}

Metode pengambilan sampel menggunakan purposive sampling. Purposive sampling adalah pengambilan sampel berdasarkan kriteria yang diinginkan. Lokasi penelitian yang dipilih sebagai lokasi pengambilan sampel adalah perairan yang berbeda berdasarkan kondisi tutupan terumbu karang. Kondisi tutupan karang yang diinginkan dalam penelitian ini adalah kondisi terumbu karang dengan kriteria baik dan kriteria rusak. Hal ini, bertujuan untuk melihat perbedaan kandungan bioaktif spons di kedua kriteria tersebut. Berdasarkan hasil observasi, ditemukan perairan dengan kondisi terumbu karang dengan kriteria baik berada pada pesisir Pantai Pulau Lara dan ditetapkan sebagai stasiun I dalam pengamatan.

Kondisi terumbu karang dengan kriteria rusak/buruk ditemukan pada perairan sekitar Tanjung Senja dan ditetapkan sebagai stasiun II dalam pengamatan. Secara umum, kedua stasiun pengamatan berada dalam wilayah perairan Teluk Staring Kabupaten Konawe Selatan Provinsi Sulawesi Tenggara. Setelah lokasi memenuhi syarat untuk dilakukan pengambilan sampel, maka lokasi tersebut ditandai dengan menggunakan GPS, hal ini untuk memudahkan dalam mencari lokasi tersebut. Peta lokasi penelitian dapat dilihat pada gambar 1 berikut. 


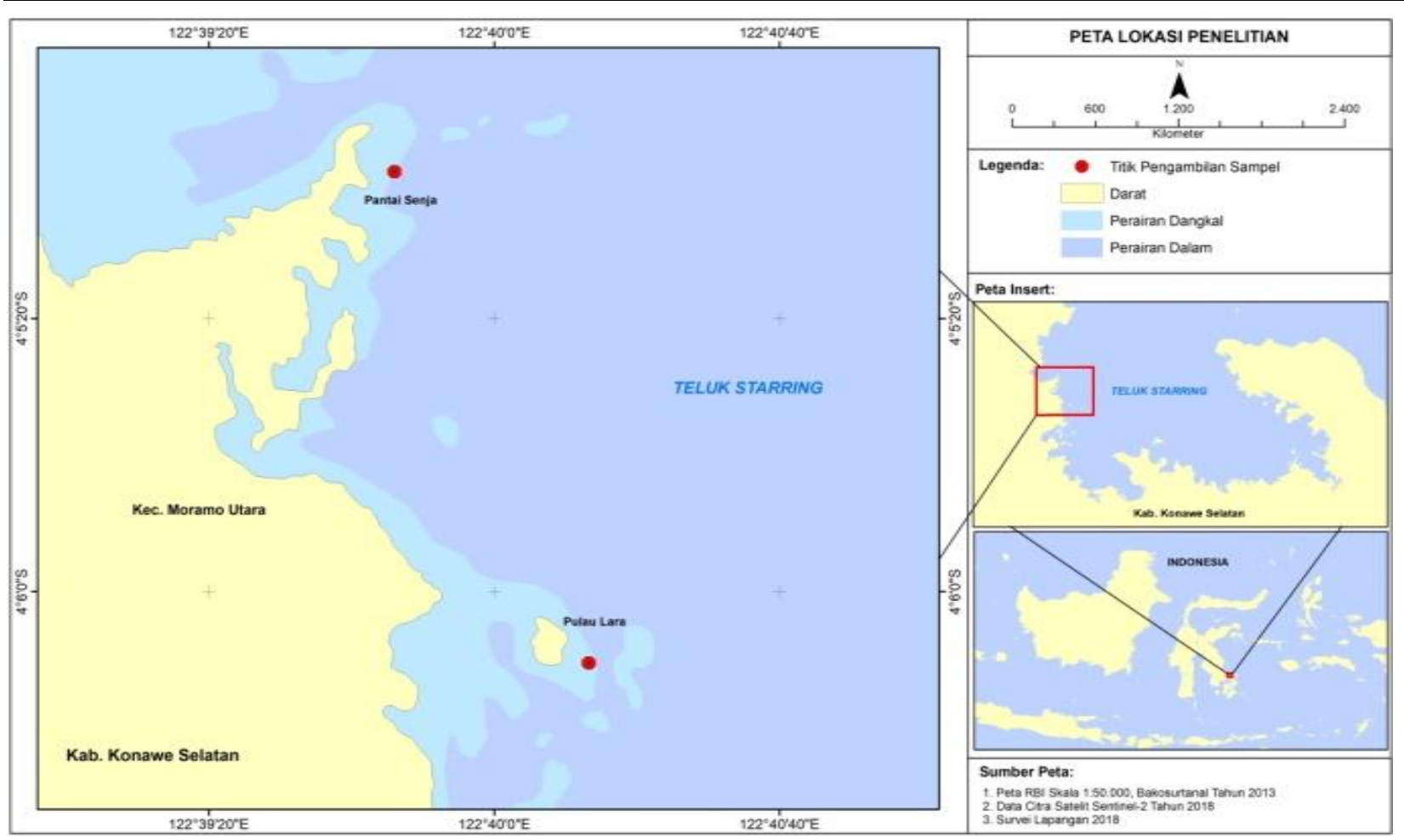

Gambar 1. Peta Lokasi Penelitian Perairan Teluk Staring.

\section{Ekstraksi}

Ekstraksi merupakan suatu proses penarikan komponen yang diinginkan dari suatu bahan dengan cara pemisahan satu atau lebih komponen dari suatu bahan yang merupakan sumber komponennya. Faktorfaktor yang berpengaruh terhadap proses ekstraksi adalah lama ekstraksi, suhu dan jenis pelarut yang digunakan (Khopkar, 2003). Metode ekstraksi tergantung pada polaritas senyawa yang akan diekstrak. Suatu senyawa menunjukkan kelarutan yang berbeda-beda dalam pelarut yang berbeda bahan dan senyawa kimia akan mudah larut pada pelarut yang relatif sama kepolarannya.

Proses ekstraksi terdiri dari beberapa tahap, yaitu pemotongan sampel, penimbangan, perendaman dengan pelarut, penyaringan, dan tahap pemisahan. Pemotongan bertujuan agar dapat mempermudah pengadukan dan kontak bahan dengan pelarutnya pada saat proses perendaman. Sampel yang telah di potong kemudian ditimbang untuk mengetahui berat awal bahan sehingga dapat diketahui rendemen yang dihasilkan. Bahan yang telah ditimbang kemudian direndam dalam pelarut. Proses perendaman yang dilakukan disebut maserasi. Maserasi merupakan metode ekstraksi dengan cara merendam bahan pelarut dengan atau tanpa pengadukan.

Prinsip pelarutan yang dipakai pada metode ini adalah like dissolve like artinya pelarut polar akan melarutkan senyawa polar dan pelarut nonpolar akan melarutkan senyawa non polar (Khopkar, 2003). Tahap selanjutnya adalah, tahap pemisahan yang terdiri dari penyaringan dan evaporasi. Penyaringan dilakukan untuk memisahkan sampel spons dengan pelarut senyawa bioaktif yang terikat dilakukan evaporasi, sehingga pelarutnya akan menguap dan akan menghasilkan hasil ekstraksi.

Spons diekstrak dengan menggunakan pelarut n-heksana untuk menghasilkan komponen nonpolar. Lama maserasi dilakukan selama 3 × 24 jam, maserasi dilakukan berulang-ulang hingga diperoleh filtrat yang bening. Hasil maserasi kemudian dipisahkan dari ampas simplisa menggunakkan kertas saring whatman lalu diuapkan menggunakan rotary vacuum evaporator pada suhu 45-50 dengan kecepatan 65-90 rpm sehingga diperoleh ekstrak pekat.

\section{Pengujian Kandungan Metabolit Sekunder}

Pemeriksaan kandungan metabolit sekunder dilakukan dengan metode kromatografi lapis tipis (KLT) dengan menggunakkan pereaksi spesifik menurut Harborne (1987).

\section{Identifikasi Alkoloid}

Ekstrak spons ditotolkan pada plat kromatografi lapis tipis, disemprot dengan pereaksi 
lieberman-buchard dan wagner. Adanya senyawa alkaloid ditandai dengan perubahan warna menjadi jingga-cokelat dengan reagen wagner. Warna putih pada pereaksi lieberman-buchard Harborne (1987).

\section{Identifikasi Fenolik}

Keberadaan kandungan senyawa fenolik ditandai dengan terbentuknya warna biru setelah penyemprotan dengan besi (III) klorida pada plat yang ditotol ekstrak spons Harborne (1987).

\section{Identifikasi Flavonoid}

Keberadaan flavonoid ditunjukkan dengan terbentuknya warna jingga sampai merah dengan penyemprotan besi (III) klorida Harborne (1987).

\section{Identifikasi terpenoid}

Keberadaan terpenoid ditandai dengan perubahan warna merah dengan pereaksi LiebermanBurchard, sedangkan biru atau ungu menunjukkan adanya steroid Harborne (1987).

\section{Identifikasi saponin}

Lapisan air dimasukkan kedalam tabung reaksi kemudian dikocok kuat. Apabila terbentuk busa yang bertahan selama 15 menit berarti positif adanya saponin Harborne (1987).

\section{Identifikasi ekstrak spons menggunakan LC/MS- MS}

Hasil analisis data LC/MS-MS akan didapatkan kromatogram berupa alur tinggi peak dan akan didapatkan bobot molekul dari senyawa yang terdapat dalam ekstrak sehingga dapat di ketahui jumlah senyawa yang dikandung setiap sampel. Liquid Chromatography Mass Spectrometry (LC/MS-MS) adalah teknik analisis yang menggabungkan kemampuan pemisahan fisik dari kromatografi cair dengan spesifisitas deteksi spektrometri massa. Kromatografi cair memisahkan komponen-komponen sampel dan kemudian ion bermuatan dideteksi oleh spektrometer massa. Data LC-MS dapat digunakan untuk memberikan informasi tentang berat molekul, struktur, identitas dan kuantitas komponen sampel tertentu, Senyawa dipisahkan atas dasar interaksi relatif dengan lapisan kimia partikel-partikel (fase diam) dan elusi pelarut melalui kolom (fase gerak) (Himawan, 2010).

Keuntungan dari LC-MS yaitu dapat menganalisis lebih luas berbagai komponen, seperti senyawa termal labil, polaritas tinggi atau bermassa molekul tinggi, bahkan juga protein.

Komponen elusi dari kolom kromatografi kemudian diteruskan ke spektrometer massa melalui antarmuka khusus Prinsipnya adalah pemisahan analit-analit berdasarkan kepolarannya, alatnya terdiri atas kolom (sebagai fasa diam) dan larutan tertentu sebagai fasa geraknya tekanan tinggi digunakan untuk mendorong fasa gerak. Campuran analit akan terpisah berdasarkan kepolarannya dan kecepatannya untuk sampai ke detektor (waktu retensinya) akan berbeda, hal ini akan teramati pada spektrum yang puncakpuncaknya terpisah (Himawan 2010).

Bantuan pompa fasa gerak cair dialirkan melalui kolom ke detektor. Cuplikan dimasukkan ke dalam aliran fasa gerak dengan cara penyuntikan. Di dalam kolom terjadi pemisahan komponen-komponen campuran, karena perbedaan kekuatan interaksi antara larutan terhadap fasa diam. Larutan yang kurang kuat interaksinya dengan fasa diam akan keluar dari kolom lebih dulu. Sebaliknya, larutan yang kuat berinteraksi dengan fasa diam maka larutan tersebut akan keluar kolom, kemudian dideteksi oleh detektor dan direkam dalam bentuk kromatogram (Isnawati 2013).

\section{Uji Aktivitas Antimikroba Metode Sumuran}

\section{a. Sterlisasi Alat dan Bahan}

Semua alat yang akan digunakan harus disterilkan terlebih dahulu dengan cara sterilisasi yang sesuai dengan masing-masing alat dan bahan yang akan digunakan. Untuk alat gelas yang tahan panas tinggi dilakukan sterilisasi kering dengan oven pada suhu $160^{\circ} \mathrm{C}$ selama 2 jam yang sebelumnya dibungkus dengan aluminium foil. Untuk medium dan akuades disterilisasi dengan car acara sterilisasi basah menggunakan autoklaf pada suhu $121^{\circ} \mathrm{C}$ selama 15 menit. Untuk larutan uji disterilkan dengan cara melakukan pengerjaan di dalam Laminar Air Flow (LAF) yang sebelumnya telah disterilisasi dengan disinfektan (alcohol 70\%) dan lampu UV yang dinyalakan 15 menit sebelum digunakan (Rahmah, 2010).

\section{b. Pembuatan Media dan Standar McFarland}

Komponen medium ditimbang dengan menggunakan timbangan analitik untuk volume yang digunakan sesuai dengan komposisi NA (agar-agar 20 g/l). Sebanyak 3,25 gram NB dan dilarutkan dalam 250 $\mathrm{mL}$ air suling di dalam Erlenmeyer lalu disterilisasi dengan autoklaf pada suhu $121^{\circ} \mathrm{C}$ selama 15 menit dengan tekanan 15 psi. Dicampurkan $0,5 \mathrm{~mL} \mathrm{BaCl} 2$ $0,048 \mathrm{~mol} / \mathrm{L}(1,175 \%(\mathrm{~b} / \mathrm{v}) \mathrm{BaCl} \cdot 2 \mathrm{H} 2 \mathrm{O})$ dan 99,5 mL H2SO4 0,18 mol/L (1\% (v/v)), diaduk campuran sampai homogen.

\section{c. Penyiapan Inokulum Mikroba}


Mikroba uji (Escerichia coli dan Streptococcus mutans) diinokulasikan dalam media pertumbuhan (NA untuk bakteri) dan diinkubasi pada suhu $37^{\circ} \mathrm{C}$ selama $1 \times 24$ jam untuk bakteri dan suhu $35^{\circ} \mathrm{C}$. Masing-masing mikroba disuspensikan pada larutan $\mathrm{NaCl}$ fisiologis steril. Suspensi bakteri diukur kekeruhannya sesuai dengan standar 0,5 McFarland menggunakan spektrofotometer $\mathrm{UV}-\mathrm{V}$ is dengan larutan $\mathrm{NaCl}$ fisiologis (CLSI, 2012).

\section{d. Pembuatan Larutan Stok dalam Uji Metode Sumuran}

Ekstrak spons dibuat empat seri konsentrasi yaitu 20.000 ppm, 10.000 ppm, 1000 ppm, 100 ppm. Sebanyak $50 \mu \mathrm{L}$ pada masing-masing sumuran. dengan menggunakkan larutan DMSO $100 \quad \% \quad$ (Dimetil Sulfoksida).

1. Pembuatan larutan induk $20.000 \mathrm{ppm}$

Stok ekstrak ditimbang $20 \mu \mathrm{g}$ dengan melarutkan 1 mL DMSO (10\%) kemudian ultrasonik sampai larut sempurna sehingga di dapatkan larutan induk dengan kadar $20.000 \mu \mathrm{g} /$ well.

2. Pembuatan larutan ekstrak uji 10.000 ppm

Dari larutan konsentrasi 20.000 di ambil menggunakan mikropipet sebanyak 10.000 ditambahkan $50 \mu \mathrm{L}$ stok ekstrak larutkan dengan 1 $\mathrm{mL}$ DMSO < $10 \%$ kemudian ultrasonik sampai larut sempurna sehingga di dapatkan larutan dengan kadar $500 \mu \mathrm{g} /$ well.

3. Pembuatan larutan ekstrak uji 1.000 ppm

Dari larutan konsentrasi $10.000 \mu \mathrm{g}$ stok ekstrak uji di ambil menggunakan mikropipet sebanyak 1000 $+50 \mu \mathrm{L}$ larutkan dengan $1 \mathrm{~mL}$ DMSO < $10 \%$ kemudian ultrasonik sampai larut sempurna sehingga di dapatkan larutan dengan kadar 50 $\mu \mathrm{g} /$ well.

4. Pembuatan larutan ekstrak uji 100 ppm

Larutan uji konsentrasi 1.000 diambil menggunakkan mikropipet sebanyak $100 \mu \mathrm{L}$ ditambahkan $50 \mu \mathrm{L}$ dilarutkan DMSO $<10 \% 1 \mathrm{~mL}$, kemudian ultrasonik sampai larut sempurna didapatkan $5 \mu \mathrm{g} /$ well.

\section{e. Uji aktivitas dengan Metode sumuran}

Metode lubang/sumuran (well) yaitu membuat lubang pada agar yang telah di inokulasikan dengan bakteri. Pada lempeng agar yang telah diinokulasikan dengan bakteri uji dibuat suatu lubang yang selanjutnya diisi dengan zat antimikroba uji, setelah di inkubasi pada suhu dan waktu yang sesuai dengan mikroba uji, dilakukan pengamatan dengan melihat ada atau tidak adanya zona hambatan disekeliling lubang (Prayoga, 2013). Metode ini digunakan untuk menjadi petunjuk adanya respon hambatan pertumbuhan bakteri dalam ekstrak. Metode sumur (difusi agar) didasarkan pada kemampuan ekstrak antimikroba yang diuji untuk menghasilkan jari-jari zona penghambatan di sekeliling sumur uji terhadap bakteri yang digunakan sebagai penguji. Setelah sterilisasi, media tuangkan kedalam cawan petri, kurang lebih sebanyak $14 \mathrm{ml}$, kemudian media dibiarkan dingin dan membeku, kemudian suspensi bakteri diinokulasikan pada seluruh permukaan media dengan cara swab menggunakan lidi kapas steril.

Media yang telah diinokulasi kultur bakteri uji tersebut dibuat lima lubang (sumur) secara aseptis dengan menggunakan tabung pembolong media dan dimasukkan larutan kombinasi ekstrak spons dan kloramfenikol dengan konsentrasi yang berbeda, yang telah dibuat sebelumnya dengan menggunakan mikropipet. Larutan kombinasi ekstrak spons yang dimasukan ke dalam sumuran sebanyak $\pm 50 \mu \mathrm{L}$.

\section{Hasil dan Pembahasan}

\section{Hasil kondisi terumbu karang}

Hasil pengukuran dan pengamatan kondisi terumbu karang di wilayah perairan Teluk Staring, menunjukkan persentase penutupan karang hidup (living coral) berkisar 65\%-19\% selengkapnya persentase kondisi penutupan terumbu karang di Perairan Staring dapat dilihat pada Tabel 2.

Tabel 2. Persentase Tutupan Terumbu Karang Di Perairan Teluk Staring.

\begin{tabular}{ccccccc}
\hline \multirow{2}{*}{ Stasiun } & \multirow{2}{*}{\begin{tabular}{c} 
Spesifik \\
\cline { 3 - 5 }
\end{tabular}} & Lokasi & HCL & HCD & $\begin{array}{c}\text { Others } \\
\text { Fauna }\end{array}$ & Abiotic \\
& & & & Kriteria & \\
\hline I & P. Lara & 65,0 & 25,0 & 8,0 & 2,0 & Baik \\
II & T. Senja & 19,0 & 44,0 & 15,0 & 22,0 & $\begin{array}{c}\text { Rusak } \\
\text { Buruk }\end{array}$ \\
\hline
\end{tabular}

\section{Pembahasan kondisi Terumbu Karang}

Terumbu karang beserta biota laut yang ada di dalamnya memiliki nilai ekonomis tinggi, akan tetapi terumbu karang merupakan ekosistem yang rentan terhadap kerusakan (Hoegh-Guldberg \& Bruno, 2010). Kerusakan terumbu karang biasanya disebabkan oleh berbagai hal, seperti: sedimentasi, pencemaran perairan, penambangan karang, penangkapan ikan yang tidak ramah lingkungan (penggunaan bom atau racun sianida), badai dan ombak yang kuat, meningkatnya populasi predator karang (Acanthaster planci), pemutihan karang karena meningkatnya suhu perairan akibat pemanasan global (Giyanto, 2017). 
Berdasaran hasil pengamatan, tipe terumbu karang yang ada di wilayah perairan Teluk Staring merupakan terumbu karang tepi (fringing reef). Terumbu karang ditemukan mulai kedalaman 1 meter pada rataan terumbu (reef flat) hingga mencapai 10 meter pada lereng terumbu (reef slope). Kemiringan lereng terumbu cukup bervariasi, yaitu mulai dari kemiringan $15^{\circ}$ (landai) hingga mencapai kemiringan $70^{\circ}$ (drop off).

Pada stasiun I penelitian berada pada titik koordinat S : 4 $4^{\circ} 04^{\prime} 54^{\prime \prime}$ dan E : $122^{\circ} 39^{\prime} 47^{\prime \prime}$. Kondisi terumbu karang pada stasiun termasuk dalam kriteria Baik dengan persentase 65,0\%. Dari 4 (empat) kategori yang ditemukan antara lain HCD, HCL, Others Fauna, dan Abiotik. HCL atau terumbu karang hidup merupakan kategori dengan persentase tertinggi dengan nilai mencapai 65,0\%. Kemudian HCD 25\%, Abiotik 2\%, dan Others Fauna $8 \%$.

Kelompok HCL atau kelompok terumbu karang hidup, ditemukan 6 (enam) kategori yang terdiri dari CB, CS, CM, ACB, ACS dan CE. Dari ke-6 (enam) kategori tersebut yang mendominasi adalah $\mathrm{CM}$ dengan nilai $28 \%$, kemudian ACB $22 \%$, CS 6\%, CB 4\%, ACS 3\%dan CE $2 \%$. Kondisi perairan yang agak terbuka dan berarus, merupakan kondisi yang memberikan peluang besar bagi CM untuk mampu bertahan hidup pada kondisi tersebut. CM merupakan terumbu karang yang kokoh yang mampu beradaptasi dengan kondisi perairan terbuka dan berarus sehingga CM dominan ditemukan pada stasiun I.

Sementara itu, kondisi karang mati pada stasiun I cukup tinggi dengan persentase mencapai $25 \%$. Tingginya persentase terumbu karang mati pada stasiun I diduga disebabkan oleh faktor alami baik itu pemangsaan predator maupun perubuhan iklim serta kegiatan penangkapan yang tidak ramah lingkungan hal ini dibuktikan dengan adanya persetase patahan karang yang mencapai 2\%. Akibat dari kondisi tersebut, terumbu karang membutuhkan waktu yang lama untuk pulih kembali.

Selain HCL dan HCD, terdapat pula kelompok Other Fauna atau organisme lain. Persentase OT pada stasiun I mencapai $8 \%$. Kelompok OT yang ditemukan pada stasiun I adalah spons (S). Pada stasiun I ditemukan pula kategori Abiotik yang didominasi oleh Sand (S) atau pasir. Pasir merupakan substrat yang labil sehingga terumbu karang tidak dapat tumbuh pada substrat tersebut karena terumbu karang membutuhkan substrat yang kasar dan kokoh untuk menempel, tumbuh dan berkembang biak.

Stasiun II berada pada Perairan Tanjung Senja. Stasiun II berdekatan dengan kawasan permukiman dan kegiatan penambangan batu. Berdasarkan hasil penelitian, kondisi terumbu karang pada stasiun II tergolong dalam kriteria Rusak Buruk. Kondisi ini dibuktikan dengan rendahnya persentase penutupan karang hidup atau HCL yang mana merupakan indikator dari kesehatan terumbu karang. Berdasarkan hasil penelitian, persentase HCL hanya mencapai 19,0\% sedangkan terumbu karang mati atau HCD mencapai $44,0 \%$. Sementara itu persentase penutupan Others Fauna 15,0\% dan Abiotik 22,0\%.

HCD atau terumbu karang mati mondominasi dasar perairan. Banyaknya terumbu karang mati pada stasiun II diduga diakibatkan oleh kegiatan penangkapan ikan yang tidak ramah lingkungan. Tutupan pecahan karang yang hancur berantakan (unconsolidated rubble). Hal ini dapat disebabkan oleh hempasan ombak atau penggunaan bahan peledak (bom) untuk menangkap ikan. Semakin banyak dijumpai pecahan karang, semakin rendah potensi pemulihan ekosistem terumbu karang dari kerusakan.

Persentase patahan karang (R) mencapai 19,0\% dan karang mati (DC) 25,0\%. Namun beberapa anakan karang baru mulai tumbuh guna untuk melakukan suksesi dan recovery atau pemulihan. Sementara itu terlihat pula hamparan pasir atau Abiotik dengan persentase penutupan yang cukup besar yaitu 22\% dan Others Fauna yang terdiri dari spons dan soft coral memiliki persentase penutupan $15 \%$.

\section{Hasil Pemeriksaan Kandungan Metabolit Sekunder}

Hasil pemeriksaan kandungan metabolit sekunder dengan menggunakan metode harborne 1997. Pada ekstrak $n$-heksana $C$. aerizusa yang di ambil di stasiun I kriteria terumbu karang baik maupun stasiun II kriteria terumbu karang buruk memiliki kandungan metabolit sekunder yang sama. Setiap masing-masing spons yang di ambil dari staiun I maupun yang di ambil dari stasiun II C. aerizusa ekstrak $n$-heksana aktif terhadap kandungan metabolit sekunder alkoloid, terpenoid, steroid, flavonoid dan saponin. Hasil pemeriksaan kandungan metabolit sekunder dapat di lihat pada tabel 3 berikut.

Tabel 3. Hasil pemeriksaan kandungan metabolit sekunder spons Ekstrak $n$-heksana C. aerizusa yang di ambil dari perairan yang berbeda

\begin{tabular}{ccc}
\hline Stasiun & Sampel Spons & $\begin{array}{c}\text { Kandungan } \\
\text { Metabolit sekunder }\end{array}$ \\
\hline I & C. aerizusa & Alkoloid \\
& & Terpenoid \\
& & Steroid \\
& & Saponin \\
\hline II & C. aerizusa & Alkoloid \\
& & Terpenoid \\
& & Steroid \\
& & Saponin \\
\hline
\end{tabular}

\section{Pembahasan Kandungan Metabolit Sekunder}

Senyawa metabolit sekunder yang dikandung oleh ekstrak $n$-heksana spons $C$. aerizusa di ambil pada 
stasiun berbeda. Perbedaaan stasiun ditandai dengan kondisi tutupan karang yang berbeda. Stasiun I penelitian kondisi terumbu karang termasuk dalam kriteria Baik dengan persentase karang hidup 65,0\%, kandungan metabolit sekunder untuk spons yang berada di stasiun ini sama antara spons yang di ambil dari stasiun I maupun stasiun II. setelah pengujian kandungan metabolit sekunder spons laut $C$. aerizusa ekstrak $n$ heksana menunjukkan noda warna plat aktif terhadap alkoloid, terpenoid, steroid dan saponin.

Stasiun II berada pada Perairan Tanjung Senja dengan titik koordinat S : 403'15" dan E : 122 39'20". Stasiun II berdekatan dengan kawasan permukiman dan kegiatan penambangan batu. Berdasarkan hasil penelitian, kondisi terumbu karang pada stasiun II tergolong dalam kriteria Rusak Buruk. Kondisi ini dibuktikan dengan rendahnya persentase penutupan karang hidup atau HCL sekitar 19,0\% yang mana merupakan indikator dari kesehatan terumbu karang. Hasil penelitian kandungan metabolit sekunder ekstrak $n$-heksana spons $C$. aerizusa area stasiun II mengandung alkoloid, terpenoid, steroid, dan saponin.

\section{Hasil Analisis LC-MS/MS}

Hasil analisis LC-MS/MS dapat mengambarkan perbedaan kandungan senyawa dari ekstrak $n$-heksana spons $C$. aerizusa yang di ambil pada kondisi terumbu karang yang berbeda. Kandungan perbedaan tersebut di gambarkan dengan crhomatogram puncak senyawa dengan berat molekul yang berbeda. Hasil pemeriksaan LC/MS-MS berat molekul senyawa yang paling banyak ditemukan pada ekstrak $n$-heksana spons $C$. aerizusa yang di ambil di stasiun I di bandingkan pada ekstrak $n$ heksana spons $C$. aerizusa yang di ambil pada stasiun II dapat dilihat melalui tabel 4 berikut.

Tabel 4. Dugaan senyawa ekstrak $n$-heksana spons $C$. aerizusa yang di ambil pada stasiun I dan Stasiun II

\begin{tabular}{|c|c|c|c|c|c|}
\hline \multirow[b]{2}{*}{ No } & \multirow[b]{2}{*}{$\begin{array}{c}\text { Nama } \\
\text { sampel }\end{array}$} & \multicolumn{2}{|c|}{ Stasiun I } & \multicolumn{2}{|c|}{ Stasiun II } \\
\hline & & $\begin{array}{l}\text { Waktu } \\
\text { retensi }\end{array}$ & Area:heigth & $\begin{array}{l}\text { Waktu } \\
\text { retensi }\end{array}$ & Area:heigth \\
\hline \multirow{13}{*}{ - } & & 0,42 & $620 ; 9425$ & 0,43 & $761 ; 11621$ \\
\hline & & 2,99 & $65 ; 1492$ & 3,69 & $263 ; 6009$ \\
\hline & & 3,70 & $208 ; 5108$ & 3,77 & $2512 ; 53756$ \\
\hline & & 3,76 & $558 ; 24451$ & 4,64 & $15804 ; 20242$ \\
\hline & & 4,00 & 933,14816 & 4,87 & $14784 ; 18178$ \\
\hline & & 4,36 & $91 ; 1792$ & 4,96 & $3555 ; 62188$ \\
\hline & C.aerizusa & 4,74 & $152 ; 3480$ & 5,15 & $2271 ; 26432$ \\
\hline & & 4,92 & $984 ; 13582$ & 6,15 & $4311 ; 107767$ \\
\hline & & 5,39 & $1859 ; 23115$ & 6,18 & $3254 ; 77224$ \\
\hline & & 5,76 & $3580 ; 47409$ & 6,31 & $4406 ; 54304$ \\
\hline & & 5,92 & $3157 ; 43160$ & 6,53 & $1468 ; 23115$ \\
\hline & & 6,66 & $559 ; 11051$ & 7,61 & $376 ; 5960$ \\
\hline & & 7,08 & $1904 ; 28191$ & 7,87 & $365 ; 13087$ \\
\hline
\end{tabular}

\begin{tabular}{lccc} 
& 7,60 & $166 ; 2705$ & \\
& 7,81 & $199 ; 4178$ & \\
\hline Jumlah senyawa & 15 & 13 \\
\hline
\end{tabular}

\section{Pembahasan Analisis LC-MS/MS}

Jenis spons yang sama memiliki kandungan senyawa yang berbeda apabila ditinjau dari kondisi tutupan karang yang berbeda. Hal ini dibuktikan dengan hasil penelitian menunjukkan pada stasiun I yang memiliki persentase tutupan karang yang baik berbanding lurus dengan banyaknya senyawa, sedangkan stasiun II yang memiliki persentase tutupan karang buruk memiliki sedikit senyawa ditemukan melalui identifikasi LC/MS-MS yang dapat di lihat pada gambar 2 berikut. Crhomatogram spons $C$. aerizusa menggambarkan 11 puncak senyawa mayor sedangkan pada yang di ambil di stasiun II crhomatogram menunjukkan sedikitnya 8 puncak senyawa.

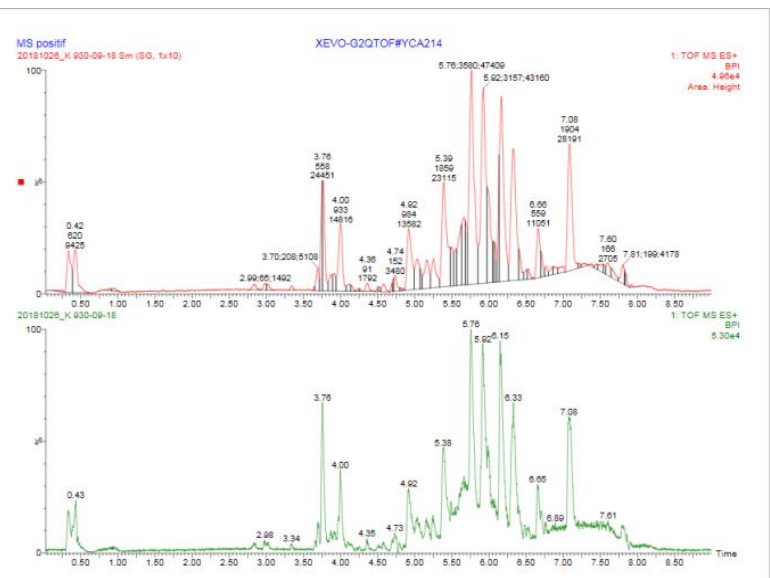

Gambar 2. Chromatogram spons C. aerizusa ekstrak nheksana stasiun I

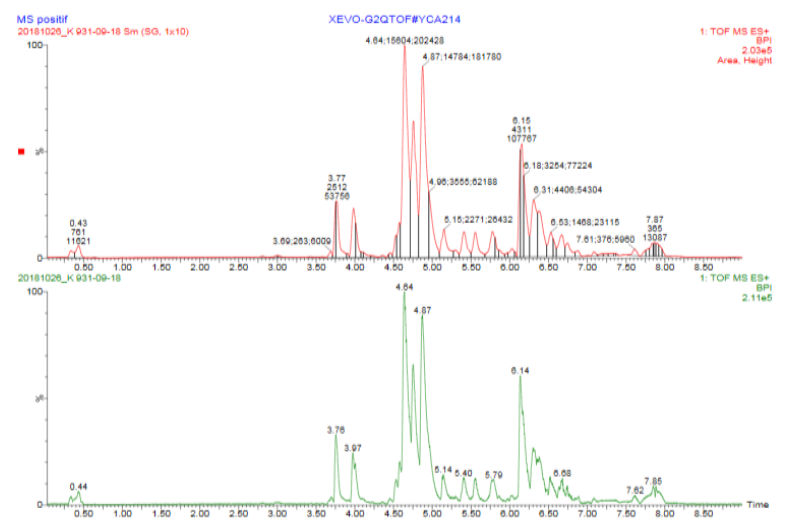

Gambar 3. Chromatogram spons $C$. aerizusa ekstrak $n$ heksana stasiun II

Keadaan ini di pengaruhi oleh lingkungan spons, keadaan stasiun I memiliki persentase tutupan karang kategori baik. Spons merupakan organisme filter fedeer dalam mengambil makanannya. Pada lokasi ini spons 
lebih banyak menyerap kandungan bahan organik yang bersifat nonpolar seperti steroid. Steroid merupakan hormon seks yang digunakan organisme karang dan spons untuk berkembangbiak di lokasi tersebut, sebagaimana diketahui lokasi terebut memiliki kondisi yang baik untuk pertumbuhan karang dan spons dikarenakan kondisi tersebut memicu kompetisi spasial untuk berkembangbiak.

Sesuai pernyataan Harper (2001) menjelaskan bahwa karang lunak menghasilkan senyawa metabolit sekunder berfungsi untuk menghadapi serangan predator, media kompetisi, mencegah infeksi bakteri, membantu proses reproduksi, dan mencegah sengatan sinar ultraviolet. Karang lunak menghasilkan beberapa dari golongan senyawa hasil metabolit sekunder, antara lain alkaloid, steroid, flavonoid, fenol, saponin, dan peptida. Lebih jelas lagi hal ini di dukung oleh Hardiningtyas (2009) melaporkan bahwa karang lunak Sarcophyton sp. banyak mengandung senyawa bioaktif steroid. Steroid dalam karang lunak terbagi menjadi dua, yaitu hormon adrenal dan hormon seks. Kedua hormon ini berperan dalam metabolisme dan pembentukan progesteron, testosteron, dan estrogen yang kemudian akan membentuk gamet jantan dan betina.

Keadaan seperti di atas yaitu pada spons laut $C$. aerizusa ekstrak $n$-heksana, stasiun dengan kategori tutupan karang baik seperti stasiun I memiliki senyawa lebih banyak di banding stasiun II ini didukung oleh penelitian Fariska (2010), yang mengemukaan agar dapat bertahan hidup di suatu perairan yang memiliki tingkat kompetisi dan predasi yang tinggi, spons $C$. aerizusa harus mempunyai mekanisme pertahanan yang kuat. Salah satu caranya adalah dengan memproduksi senyawaan yang memiliki aktivitas bioaktif yang tinggi.

Fariska, 2010 juga menjelaskan kondisi ekologis yang baik dapat tercermin dari kondisi ekosistem terumbu karangnya. Ekosistem terumbu karang yang baik memiliki keanekaragaman biota yang relatif tinggi termasuk biota spasial pesaing maupun predator spons. Beberapa predator umum yang memangsa spons adalah dammselfish (pomacentriadae) seperti abudefduf dan lain-lain. keberadaan predator spons memungkinkan tingkat predasi yang terjadi lebih tinggi dibandingkan zona pemukiman. Sedangkan organisme pemangsa spons pada stasiun I ditemukan predator umum yaitu dammselfish (pomacentriadae) seperti abudefduf, wrase (labridae) seperti thalassoma, halichoeres.

Terjadinya kompetisi ruang, makanan, dan adanya presator pemangsa memicu spons untuk memproduksi metabolit sekunder yang berperan sebagai allelopatic agent. Hardiningtyas (2009) menyatakan bahwa allelopatik adalah sifat penghambat secara langsung terhadap suatu jenis oleh jenis lainnya dengan menggunakan zat-zat kimia.

\section{Pengujian aktitivitas antibakteri}

\section{Hasil pengujian aktivitas antibakteri}

Berdasarkan screening aktivitas antibakteri pada spons laut $C$. aerizusa ekstrak $n$-heksana terhadap bakteri E. coli dan S.mutans. Hasil penelitian memperlihatkan semakin tinggi konsentrasi semakin besar pula zona hambatan yang terbentuk di sekitar sumuran. Spons C. aerizusa ekstrak $n$-heksana tidak dapat menghambat aktivitas bakteri $E$. coli dan dapat menghambat aktivitas $S$. mutans. Dapat dilihat pada tabel 5 dan 6 berikut.

Tabel 5. Daya hambat ekstrak $n$-heksana Spons $C$. aerizusa pada aktivitas bakteri $E$. coli

\begin{tabular}{cccc}
\hline $\begin{array}{c}\text { C.aerizusa } \\
\text { (Stasiun I) }\end{array}$ & $\begin{array}{c}\text { Daya } \\
\text { hambat }\end{array}$ & $\begin{array}{c}\text { C. aerizusa } \\
\text { (Stasiun II) }\end{array}$ & $\begin{array}{c}\text { Daya } \\
\text { hambat }\end{array}$ \\
\hline Konsentrasi & & Konsentrasi & \\
\hline $20.000 \mathrm{ppm}$ & - & $20.000 \mathrm{ppm}$ & - \\
$10.000 \mathrm{ppm}$ & - & $10.000 \mathrm{ppm}$ & - \\
$1000 \mathrm{ppm}$ & - & $1000 \mathrm{ppm}$ & - \\
$100 \mathrm{ppm}$ & - & $100 \mathrm{ppm}$ & - \\
\hline
\end{tabular}

Tabel 6. Daya hambat ekstrak $n$-heksana Spons $C$. aerizusa pada aktivitas bakteri S.mutans

\begin{tabular}{cccc}
\hline $\begin{array}{c}\text { C. aerizusa } \\
\text { (Stasiun I) }\end{array}$ & $\begin{array}{c}\text { Daya } \\
\text { hambat }\end{array}$ & $\begin{array}{c}\text { C. aerizusa } \\
\text { (Stasiun II) }\end{array}$ & $\begin{array}{c}\text { Daya } \\
\text { hambat }\end{array}$ \\
\hline Konsentrasi & & Konsentrasi & \\
\hline $20.000 \mathrm{ppm}$ & $5 \mathrm{~mm}$ & $20.000 \mathrm{ppm}$ & $4 \mathrm{~mm}$ \\
$10.000 \mathrm{ppm}$ & $4 \mathrm{~mm}$ & $10.000 \mathrm{ppm}$ & $3 \mathrm{~mm}$ \\
$1000 \mathrm{ppm}$ & $3 \mathrm{~mm}$ & $1000 \mathrm{ppm}$ & $3 \mathrm{~mm}$ \\
$100 \mathrm{ppm}$ & $2 \mathrm{~mm}$ & $100 \mathrm{ppm}$ & $2 \mathrm{~mm}$ \\
\hline
\end{tabular}

\section{Pembahasan potensi antibiotic}

Penelitian ini menggunakan metode eksperimental untuk mengetahui daya hambat ekstrak $n$ heksana spons laut $C$. aerizusa terhadap aktivitas pertumbuhan bakteri $E$. coli dan $S$. mutans. Penelitian ini menggunakan metode sumuran Kirby-Bauer dengan membuat lubang berdiameter $0,2 \mathrm{~mm}$ pada agar padat dan semi padat yang telah diinokulasi dengan bakteri. Jumlah dan letak lubang disesuaikan dengan tujuan penelitian, kemudian masing-masing lubang diisi dengan ekstrak yang akan diuji sebanyak 20 ul serta kloramfenikol sebagai kontrol positif.

Antibiotik yang digunakan dalam penelitian sebagai kontrol positif yaitu kloramfenikol. Dari penelitian ditemukan zona bening pada semua kontrol positif. Zona bening yang terbentuk di sekitar sumur pada media MHA dan MHB menunjukkan kemampuan ekstrak spons laut dan kontrol positif dalam menghambat pertumbuhan bakteri. Adapun kategori ketentuan antibakteri menurut David 1971, sebagai berikut: daerah 
hambatan $20 \mathrm{~mm}$ atau lebih berarti sangat kuat, daerah hambatan 10-20 $\mathrm{mm}$ berarti kuat, 5-10 $\mathrm{mm}$ berarti sedang dan daerah hambatan $5 \mathrm{~mm}$ atau kurang berarti lemah.

Bakteri E.coli merupakan bakteri gram negatif yang digunakan sebagai bakteri uji dalam hasil pengamatan sampel spons laut terhadap bakteri ini tidak terlihat zona hambat ekstrak $n$-heksana $C$. aerizusa pada stasiun I dan stasiun II. E.coli tidak memperlihatkan kemampuan daya hambat hal ini disebabkan bakteri $\mathrm{E}$. coli memiliki tiga lapisan dinding sel yaitu lipoposakarida, peptidoglikan dan protein (Nurfadilah 2011) sehingga senyawa yang terkandung pada ekstrak $n$-heksana spons $C$. aerizusa yang berasal dari stasiun I dan II tidak dapat merusak dinding sel pada bakteri E.coli (Pelczar, 1958). Didukung pula oleh, Zuhud (2001) menyatakan bakteri gram negatif memiliki sistem seleksi terhadap zat-zat asing yaitu pada lapisan polisakarida.

Hasil penelitian menunjukkan semakin tinggi konsentrasi ekstrak maka semakin besar pula zona bening pada sumuran seperti hasil pengujian antibakteri zona bening yang terbentuk disekitar sumur ekstrak $n$ heksana spons laut $C$. aerizusa yang di ambil di stasiun I terhadap bakteri $S$. mutans konsentrasi paling tinggi 20.000 ppm memiliki daya hambat $5 \mathrm{~mm}$ dengan interprestasi sedang. Konsentrasi 10.000 ppm memiliki daya hambat $4 \mathrm{~mm}$. Konsentrasi $1.000 \mathrm{ppm}$ memiliki daya hambat $3 \mathrm{~mm}$ dan Konsentrasi 100 ppm memiliki 2 $\mathrm{mm}$ dengan interprestasi lemah. ekstrak $n$-heksana spons laut $C$. aerizusa yang di ambil di stasiun II terhadap bakteri $S$. mutans konsentrasi $20.000 \mathrm{ppm}$ memiliki zona hambat $4 \mathrm{~mm}$ interprestasi lemah semakin kecil konsentrasi semakin kecil pula zona hambat yang terbentuk.

Bakteri S. mutans merupakan bakteri gram positif. Berdasarkan hasil pengamatan yang dilakukan pada uji daya hambat dengan pemberian ekstrak spons laut $C$. aerizusa ditemukan adanya zona hambat terhadap bakteri S.mutans kepada semua ekstrak spons laut mulai dari konsentrasi 20.000 ppm, 10.000 ppm, 1000 ppm dan 100 ppm walaupun memiliki interprestasi lemah.

\section{Kesimpulan}

Perbedaan Kondisi terumbu karang akan berbeda pula kandungan bioaktif pada spons C. aerizusa. Kandungan Metabolit Sekunder untuk C. aerizusa dari kedua stasiun sama aktif terhadap alkoloid, steroid, flavonoid, terpenoid, dan saponin. Analisis LC-MS/MS (Liquid Crhomatogaph Mass Spectrometry) menunjukkan pada stasiun I terdapat 15 jumlah senyawa sedangkan stasiun II terdapat 13. Potensi Antibakteri Ekstrak $n$-heksana Spons $C$. aerizusa untuk stasiun I dan
II tidak aktif terhadap E. coli namun Spons $C$. aerizusa stasiun I dan II aktif terhadap aktivitas $S$. mutans.

\section{Ucapan Terima Kasih}

Terima kasih penulis ucapkan kepada dewan pembimbing dan rekan-rekan yang terlibat dalam proses penelitian ini hingga akhir dan tidak lupa pula penulis sampaikan terima kasih kepada direksi Jurnal Biologi Tropis yang telah bersedia menerbitkan artikel penulis dengan judul Analisis Lc-Ms/Ms (Liquid Crhomatogaph Mass Spectrometry) dan Metabolit Sekunder Serta Potensi Antibakteri Ekstrak n-Heksana Spons Callyspongia Aerizusa yang diambil pada kondisi tutupan terumbu karang yang berbeda di perairan Teluk Staring.

\section{Daftar Pustaka}

CLSI. (2012). Methods for Dilution Antimicrobial Suspectibility Test for Bacteria that Grow Aerobically; Aproved Standard. $9^{\text {th }}$ Edition. Clinical and Laboratory Standard Institute, 32 (2):16-19.

COREMAP-CTI (2017). Pusat Penelitian Oseanografi LIPI Jakarta

Davis, W.W. \& T. R. Stout (1971). Disc Plate Method of Microbiological Antibiotic Assay. Applied Microbiology. 22: $659-665$.

De Voogd, N. J. (2005). Indonesian sponss "Biodiversity and mariculture potential".The Royal Netherlands Academy of Sciences, Amsterdam: $174 \mathrm{pp}$.

Ditjen POM (1995). Farmakope Indonesia Edisi IV. Jakarta: Departemen Kesehatan Republik Indonesia.

Fadilah (2013). Uji bioaktifitas antibakteri ekstrak dan Fraksi lamun dari kepulauan spermonde Kota makassar. Universitas Hasanuddin.

Fariska Yudha (2010). Studi Ekologi Senyawaan Spons Callispongia aerizusa Desqueyroux-Faundez, 1984. Dari Kepulauan Seribu, Jakarta. Seminar Nasional Biologi. Departemen Biologi. FMIPA UI.

Giyanto (2017). Status terumbu karang Indonesia. Coremap-CTI Pusat Penelitian Oseanografi-LIPI. Jakarta.

Harborne, JB. (1987). Phytochemical Methods. New 


\section{York. Chapman and Hall Ltd.}

Hardiningtyas, S.D. (2009). Aktivitas antibakteri ekstrak karang lunak Sarcophyton sp yang difragmentasi dan tidak difragmentasi di perairan Pulau Pramuka, Kepulauan Seribu. Departemen Teknologi Hasil Perairan, Fakultas Perikanan dan Ilmu Kelautan, Institut Pertanian Bogor.

Harper, M.K.; T.S.Bugni; Copp; .James; B.S.Lindsay \& C.M.Ireland (2001). Introduction to the chemical ecology of marine natural products. In:Marine Chemical Ecolology. CRC Press USA 3-29 p

Himawan R. F. (2010). Kromatografi Cair Kinerja Tinggi (KCKT).

Hoegh-Guldberg, O. \& Bruno, J.F. (2010). The Impact of Climate Change on the World's Marine Ecosystems. Science, 328, 1523-1528.

Intiyani, Sadarun \& Sahidin (2014). Kajian Potensi Aktivitas dan Metabolit Sekunder Beberapa Jenis Spons. Disampaikan Seminar Nasional Perikanan Berkelanjutan II. Fakultas Perikanan dan Ilmu Kelautan. Universitas Halu Oleo. Kendari.

Isnawati R. (2013). Kromatografi Cair Kinerja Tinggi (HPLC)

Janssen, APHM. (2001). The Prence of Spons-Dwelling Endofauna in Reation to Spons Productivity.

Keputusan Menteri Negara Lingkungan Hidup Nomor 4 Tahun 2001 Tentang Karang Berdasarkan KEPMEN LH No. 4 Tahun 2001.

Khatab RMA, Ali AE, El-Nomary B. \& Temraz TA (2008). Screening For Antibacterial And Antifungal Activities Some Selected Marine Organisms Of The Suez Canal And Red Sea, Egypt Journal Exp Biol (Zool), 4(8):223-228.
Khopkar SM. (2003). Konsep Dasar Kimia Analitik. Jakarta, Universitas Indonesia-Press

Krisyuninda (2012). Uji Toksisitas Spons Callyspongia sp. dengan metode brine shrimp test dari perairan pasir putih situbondo. Institut Teknologi Sepuluh November. Surabaya

Marzuki, I. (2018). Eksplorasi Spons Indonesia Seputar Kepulauan Spermonde. Nas Media Pustaka. Makassar.

Muniarsih, T. \& Rachmaniar, R. (1999). Isolasi Substansi Bioaktif Antimikroba dari Spons Asal Pulau Pari Kepulauan Seribu. Prosiding Seminar Bioteknologi Kelautan Indonesia 98. Jakarta Pengetahuan Indonesia Jakarta. hal. 15 -158.

Nofiani, R. (2008). Artikel ulas balik: Urgensi dan mekanisme biosintesis metabolit sekunder mikroba laut. Jurnal Natur Indonesia 10(2):120125

Pelczar M.J. \& Reid RD. (1958). Mikrobiology. Tokyo: McGraw-Hillbook Company.Inc.

Prayoga (2013). Perbandingan efek ekstrak daun sirih hijau (Piper betle L.) dengan metode difusi disk dan sumuran terhadap pertumbuhan bakteri Staphylococcus aureus. Kementerian Kesehatan Republik Indonesia. Jakarta.

Rumampuk, Wowor \& Mambo (2017). Uji Daya Hambat Ekstrak Spons Laut (Callyspongia aerizusa) terhadap Pertumbuhan Bakteri Salmonella Typhi dan Streptococcus Pyogenes). Jurnal e-Biomedik (eBm). 5 (2) : Juli-Desember.

Zuhud, E.A.M, Winiati P.R, Hanny,W.C \& Pipi, P.S, (2001). Aktivitas antimikroba ekstrak kedaung (Parkia roxburghii G Don) terhadap bakteri pathogen,Teknol \& Indusri Pangan, XII (1): 6-12. 